\title{
NOTE ON THE OCCURRENCE OF SPONGE REMAINS IN THE LOWER SILURIAN OF NEW SOUTH WALES.
}

\section{By W. S. Dun.}

Until last year it was thought that fossiliferous rocks of Lower Silurian age did not occur within the geographical boundaries of New South Wales. Mr. J. E. Carne, who was then making a geological examination of the south-eastern border country, came across extensions, from Victoria, of the graptolite-bearing slates. From several localities in the County of Wellesley he collected numerous specimens of a blue-black slate showing in great number rather indistinct remains of Graptolites. These remains were, unfortunately, rather unsatisfactory, being preserved as white films, showing only the outlines of the colonies. A preliminary note on these has already been published, ${ }^{*}$ and tentative specific names have been given to some of the forms. As will be seen from the list, the forms belong chiefly to Diplograptus :-

Dicranograptus furcatus, Hall.

Dicellograptus extensus, Hall.

, sp.

Didymograptus (? caduceus, Salter).

Diplograptus, cf. mucronatus, Hall.

„ $\quad$ cf. rectangularis, McCoy.

, $\quad$ ef. palmeus, Barrande.

Phyllograptus (?).

Climacograptus.

It has already been pointed out by Mr. T. S. Hall that the general facies of the graptolite fauna of Ordovician slates in north-eastern Gippsland would appear to point to the rocks being of a more recent age than the slates containing Phyllograptus, \&c., in the Castlemaine and Bendigo District. $\dagger$ It is, I think,

* Records Geol. Survey N.S. Wales, 1897, v. Pt. 3, pp. 124-127. † Proc. R. Soc. Vict., 1897, ix. (N.S.), pp. 183-186. 


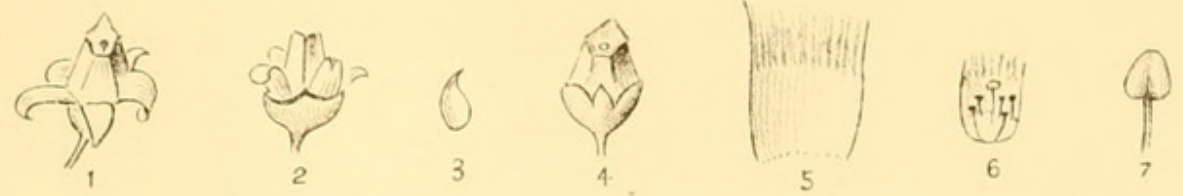

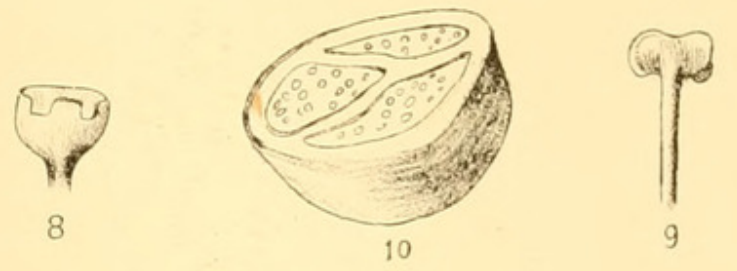

ARGOPHYLLUM sp. Forst. Char. Gen.Pl. t. 3 a.

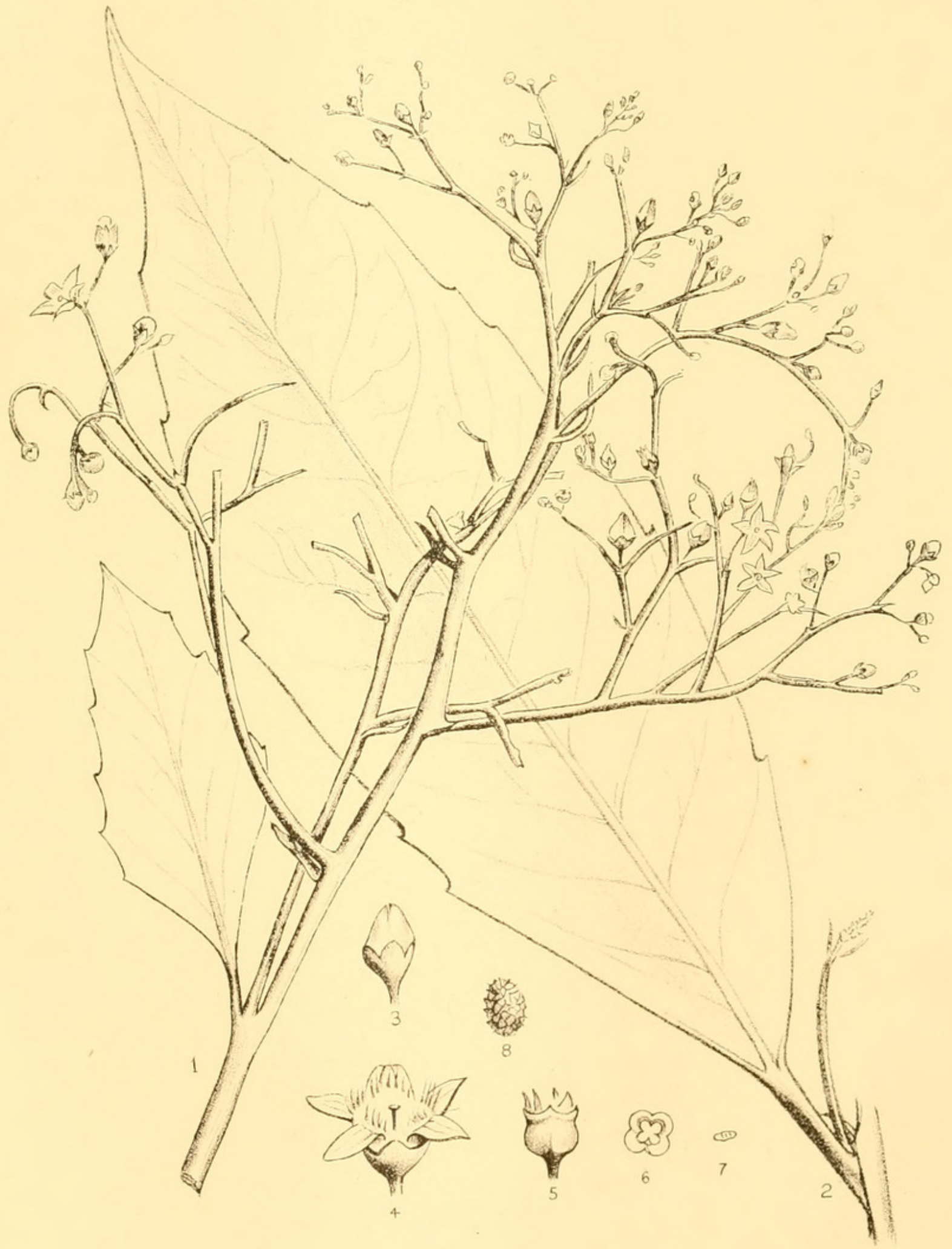




\section{$2 \mathrm{BHL}$ Biodiversity Heritage Library}

Dun, W S. 1897. "Note on the occurrence of sponge remains in the Lower Silurian of New South Wales." Proceedings of the Linnean Society of New South Wales 22, 436-437. https://doi.org/10.5962/bhl.part.12727.

View This Item Online: https://www.biodiversitylibrary.org/item/22896

DOI: https://doi.org/10.5962/bhl.part.12727

Permalink: https://www.biodiversitylibrary.org/partpdf/12727

\section{Holding Institution}

MBLWHOI Library

\section{Sponsored by}

MBLWHOI Library

\section{Copyright \& Reuse}

Copyright Status: NOT_IN_COPYRIGHT

This document was created from content at the Biodiversity Heritage Library, the world's largest open access digital library for biodiversity literature and archives. Visit BHL at https://www.biodiversitylibrary.org. 